\title{
Ghana's Oil Discovery and Natural Resource Curse Nexus
}

\author{
George Asumadu ${ }^{*}{ }^{\mathbb{D}}$, Daniel Ofori², John Agyei ${ }^{3}$, Ali Yahuza Bawa ${ }^{4}$ \\ ${ }^{1}$ Department of Accountancy and Accounting Information Systems, Kumasi Technical University, Kumasi, Ghana \\ ${ }^{2}$ Department of Entrepreneurship and Finance, Kumasi Technical University, Kumasi, Ghana \\ ${ }^{3}$ Institute of Research, Innovation and Development, Kumasi Technical University, Kumasi, Ghana \\ ${ }^{4}$ Registry, Kumasi Technical University, Kumasi, Ghana \\ Email: ^gasumadu@gmail.com
}

How to cite this paper: Asumadu, G., Ofori, D., Agyei, J., \& Bawa, A. Y. (2021). Ghana's Oil Discovery and Natural Resource Curse Nexus. Modern Economy, 12, 1959-1971.

https://doi.org/10.4236/me.2021.1212103

Received: November 5, 2021

Accepted: December 25, 2021

Published: December 28, 2021

Copyright $\odot 2021$ by author(s) and Scientific Research Publishing Inc. This work is licensed under the Creative Commons Attribution International License (CC BY 4.0).

http://creativecommons.org/licenses/by/4.0/

(c) (i) Open Access

\begin{abstract}
This paper draws on the concept of the natural resource curse theory, the Dutch disease, to critically review the impact of Ghana's oil discovery on the performance of the agricultural sector through a desk review. We also combed on the various directories for articles in academic journals, bulletins, governmental and non-governmental reports and magazines for any salient data on the topic. Drawing on the experiences of other countries on Dutch disease, we argue that the dwindling performance of the agricultural sector after the discovery of oil and gas is a reflection of Dutch disease. We recommend that the government take proactive measures to ensure balance and engineer growth in the agricultural sector which is the mainstay of the majority of the citizenry. Measures such as youth in agricultural programmes, planting for food and jobs, subsidies, and recognition to successful farmers should be encouraged to ensure that the productive base of the sector is working to propel GDP growth.
\end{abstract}

\section{Keywords}

Dutch Disease, Ghana's Oil and Gas Discovery, Agricultural Sector, Economy

\section{Introduction}

Ghana is an emerging economy endowed with valuable natural resources, such as gold, bauxite, aluminum, and crude. In 2010, the production of oil in commercial quantities was one of the triggers leading to Ghana's attainment of a middle-income status ahead of the vision 2020 national agenda (ICAI, 2020). Through the Ghana National Petroleum Council (GNPC) oil exploration in 
2007, and a US-based company called Kosmos Energy, about 75 miles of offshore oil was discovered often called the "jubilee field". One of the world's largest oil discoveries is estimated to hold approximately 1.8 billion barrels of recoverable oil and 800 billion cubic feet of natural gas (Kapela, 2009; Kwawukume, 2012). Of course, this came as good news to the country given its potential to boost the economy, enhance infrastructural developments, and offer employment which are major challenges facing the economy. The discovery of oil is expected to move the country as a net exporter of oil, generating billions of dollars to push the country's development in many facets. However, this assumption is not entirely real, as the path of development from the experience of other economies has eluded them, leading to the degeneration of other productive sectors (Czech \& Imbeah, 2019). The exploration of newly-discovered valuable natural resources like oil and gas provides significant income to aid development but how these gains are spent can create adverse macroeconomic upheavals that cripple other sectors, making it lose its international competitiveness in what is mostly referred to as the Dutch disease, a concept others refer to as an "a natural resource abundance curse" or "the paradox of plenty" (Henstridge \& Roe, 2018; Elwerfelli \& Benhin, 2018; Graham et al., 2019).

The natural resource abundance curse is used to explain the incapability of nations endowed with natural resources to reap lasting benefits from the exploitation of natural resources (Humphreys et al., 2007). As Ghana continues preparing to expand her share of oil income, one does not need to look more distant than the nation's involvement with mining, to be reminded that the most extreme alert is needed. This is because the Ghanaian mining industry is an illustrative example of how an extractive industry turns into a disengaged enclave economy, as opposed to a growth engine with positive spin-offs in the entire economy (Aryeetey \& Baah-Boateng, 2016). That is, the natural resource rent affects the economic growth asymmetrically (Opoku \& Buabeng, 2021; Lashitew \& Werker, 2020).

The Dutch disease is an economic theory that conceptually emanated from the Netherlands, now Holland in the 1960s as a result of the exploitation and tapping of the newly found gas reserves positioned in the north sea; revenues denominated in hard currencies were earned and the domestic Dutch gilder began to appreciate in value sharply, hurting non-oil sector like "agriculture and manufacturing" and their exports dwindled in the world markets, with an overall negative effect on the whole economy, leaving oil or hydrocarbons to dominate the economy (Oyesami, 2011; Ibe \& Ihejirika, 2018). Her initial source of economic sustenance is agricultural output exports. The agriculture sector performance has been dicey and data available indicates that the sector's share of GDP has been declining from 20.08\% in 2017 to $18.24 \%$ in 2020 (Global Economy, 2021; ILO, 2020; Essegbey \& MacCarthy, 2020). In 2019, the agriculture sector absorbed about $33.50 \%$ of the labour force and it is the second-largest employer but it is the smallest sector in comparison to services and industry sectors. The agriculture sector in the country is still dominated by smallholding farmers and 
is rain-dependent. Modern technology still eludes the sector, making it threatened by oil and gas discovery (Itrade.gov.il, 2021). Despite her potential in agriculture, Ghana is a net importer of basic food including rice, poultry, sugar and vegetable oil (World Bank, 2017a). It is also well-document that public expenditure on agriculture is below the $10 \%$ of GDP as agreed in the Maputo Declaration (Ibid). Dutch disease occurs when a country discovers a substantial natural resource deposit and begins large-scale exportation. Researchers have dubbed the adverse effects of a resource boom as Dutch disease. Dutch disease is used to describe a reduction in a country's traditional and non-traditional export (or manufacturing) performance as a result of an appreciation of the real exchange rate after natural resources such as oil and gas discovery and exploitation (Barder, 2006).

According to Weinthal and Luong (2006), natural resources provide an opportunity to significantly contribute to poverty reduction and improve the well-being of people, more specifically in communities where resources are discovered and extracted. Thus, natural resources are supposed to be a blessing and not a curse. However, most resource-endowed nations in Africa are poorer, with less economic growth in the long run than those deprived of natural resources. Ghana discovered commercial hydrocarbons in 2007 and began production in 2010 (Abudu \& Sai, 2020). Many of the people rooted in the discovery as assumptions were that this newly found sector (boom sector) will contribute significantly to the nation's economic growth and development. These assumptions were not so, as the discovery raised much concern. According to the World Bank (2017b), most natural resource-endowed nations in Africa and Botswana have one way or the other felt some form of the natural resource-curse syndrome, due to the slow pace of poverty reduction.

However, given the experiences of developed and developing countries, this oil found in Ghana will have both favourable and unfavourable effects on the economy. Consideration of the favourable effects of oil and gas is obvious in terms of employment and revenue to promote development. In Dutch disease, savings accruing from the importation of oil and gas can also be considered as a favourable effect which can also be used to promote development. The catch here is to give more attention to the unfavourable effects that the booming sector has on the economy as a whole. The unfavourable effects in the economics literature have been described as Dutch diseases. It was believed that Ghana would avoid this disease that had prevented countries such as Nigeria, Venezuela, and Angola from enjoying the full benefits of their oil find. Sadly, it seems that the country has not escaped the Dutch disease with farmlands in communities near the oil fields taken over, food production has reduced. The euphoria associated with the oil discovery and structural changes in the economy, where there has been population drift from rural agriculture areas to urbanization without adequate service and industry job openings has exacerbated the natural resource curse parody in the country (Diao et al., 2019; Okpanachi \& Andrews, 2012). Through a desk review, the study seeks to critically examine the pattern of sec- 
toral performance with a special focus on the agricultural sector before the discovery of the oil field and before and to determine if there is a Dutch disease in Ghana. This will inform development planning and send a signal to policymakers on the need to diversify and build a broad base so as to meet the needs of the present without compromising the ability of future generations to meet their own needs. This paper is made up of five main sections, namely introduction, methodology, review of concepts and issues, discussion as well as conclusion.

\section{Methodology}

For this work to be given any credence, an array of secondary data (literature) spanning from macroeconomic policies on Dutch disease syndrome in emerging economies, especially in Sub-Saharan Africa (SSA), natural resources sustainability and production capacity, using agricultural products and export processing zones in Ghana from 2008 to 2019. We also combed on the Internet for articles in academic journals, bulletins, governmental and non-governmental reports and magazines for any salient information on the topic areas. The documents were then synthesised and focused on what would give meaning to the scope of the audience based on the journal that we wanted to publish in. This method was chosen to be able to stress the eminent of the rich-natural resource curse associated with many developing economies, and Ghana should be aware of not falling into the resource-curse web. This research design has been descriptive in nature and it falls on the work of Rosnow and Rosenthal (2002). Also, the oil discovery activities in Ghana are at their infancies compared to neighbouring countries in Sub-Saharan Africa, namely Nigeria, Gabon and Angola. Hence, using primary data at this COVID-19 restriction would be daunting and costly. Most of the data were retrieved from Google Scholar, Science Direct, Web of Science and other websites, linking Ghana's oil and gas discovery with the natural resource curse syndrome.

\section{Critical Review of the Concepts and Issues}

\subsection{Booming Sector Theory}

The booming sector theory reflects on the sectoral distribution that can arise as a result of a rapid rise in revenue, such as discovering huge reserves of natural resources. The central model of Dutch disease, illustrated by Corden (1984), focuses on three sectors: the booming, lacking, and non-tradable sectors. Booming and lacking sectors are tradable industries. This means that they are involved in international trade, which involves imports and exports, and thus compete with the prices of the global market. The non-tradable sector provides domestic services, where prices are regulated by domestic supply and demand. The allocation of the lacking sector to the booming sector may be due to the effect of resource movement or spending (Ibid). The consequence of resource movements is that the appreciation of the exchange rate triggers labour and service movements in the booming sector. The result of investment (spending effect) is that the boom- 
ing industry requires comparatively limited resources from the lacking sector, but the income is invested locally, which allows the exchange rate to appreciate (Ibid).

In Ghana, the booming sector is listed as new oil industry and a lacking sector as the other exporting sectors, such as agriculture. The allocation is calculated by the spending effect, as the oil industry does not need its labour force from the lack of industry, but is regulated by high oil revenues. The work force in the oil industry is a highly densed labour force, relative to the labour force in the agricultural sector, since the turnover of the oil industry is higher than that of the agricultural industry, but the demand for labour is lower (Ibid). This results in an appreciation of the exchange rate, thereby weakening the global competitiveness of the lacking sector. According to the exchange rate hypothesis, domestic commodities have become more costly for international consumers to import, making the lacking sector worse off. There will also be a transition of resources from the lacking sector to the booming sector. This is also known as indirect de-industrialization (Ibid).

Based on literature (Kuzu \& Nantogmah, 2010; Steffensen et al., 2011; Kumah-Abiwu et al., 2015; Kopiński, Polus, \& Tycholiz, 2013) as well as (Czech \& Imbeah, 2019), the plausible economic effects of the Dutch disease syndrome and the Resource Curse Thesis can be summarized as follows:

- Structural change and a booming sector;

- Movement of labour from the traditional/non-traditional (or manufacturing) export sector to the booming sector;

- Decreasing profit for exporters (traditional/non-traditional or manufacturing exporters);

- Decreasing traditional/non-traditional or manufacturing exports;

- Exportation of oil and gas on large scale;

- Increased government revenues through increased inflows in foreign exchange;

- Increased incomes for factors of production and non-traded output;

- Inflation;

- Appreciation of the real exchange rate;

- Structural unemployment and increased unemployment;

- Increased imports;

- Corruption and rent-seeking activities;

- Low economic growth.

These outcomes will need to be handled to allow Ghana to gain as much as possible from the oil and gas industry. The performance of the agricultural sector before and after the discovery of oil is discussed in the next section.

\subsection{Dutch Disease and the "Mixed" Story of Other Countries}

In the past decades, a large body of literature on the Dutch disease phenomenon has examined the commodity booms experienced by some economies. However, these studies have mostly focused on industrialised and developed countries, and 
on the abundance of natural resources, leaving small open economies and transition countries virtually outside the analysis, as well as other forms of Dutch disease. Indeed, only a few empirical studies have been undertaken on the particular case of Central and Eastern European countries or for the rest of the former Soviet Union.

In March 2010, the European Commission launched the 2020 Strategy to overcome the negative effects of the financial and economic crisis in 2008 and prepare the EU economy for the next decade by promoting convergence and potential long-term economic growth in EU member countries. Bearing in mind that in Central and Eastern Europe, there are 11 member countries of the EU (Bulgaria, Croatia, Estonia, Latvia, Lithuania, Hungary, Poland, Czech Republic, Romania, Slovenia, and Slovakia), six countries of the former Yugoslavia (Albania, Bosnia-Herzegovina, Macedonia, Montenegro, Serbia, and Kosovo), and four former Soviet republics (Belarus, Moldova, Ukraine, and Russia), and the analysis of the phenomenon of Dutch disease within this group of countries has become very important, not only to gain an understanding of the effectiveness of attracting and using EU funds but also to obtain a better knowledge of the transition and enlargement process in the EU. Andrade and Duarte (2017) reviewed the economic literature devoted to the analysis of the Dutch disease phenomenon in this type of economy. He began by analysing the phenomenon in some of the post-Soviet transition economies, such as Azerbaijan, Kazakhstan, Turkmenistan, and Uzbekistan, concentrating later on Central and Eastern European countries and concluded that there is no wide consensus that countries whose economic structures depend on natural resource abundance are necessarily penalised in the long run in terms of competitiveness and economic growth. For instance, Hasanov (2013) empirically tested some of the main hypotheses of the Dutch disease phenomenon in the Azerbaijan economy, one of the most important natural resource-rich countries of the former Soviet bloc, observing that the Azerbaijan economy, as many other resource-abundant (mainly oil) economies have experienced substantial economic growth over the last several years. Oil extraction and oil exports have been growing substantially, thus becoming a leading sector in the economy. Huge oil revenues, driven by high oil prices and an expansion of oil production, have been the major sources of the enormous increase in government expenditures in the form of infrastructure and social projects, which are useful for socio-economic development. However, the boom in the oil sector has also been accompanied by negative economic trends. The objective of Hasanov (Ibid) was to diagnose Dutch disease symptoms in the Azerbaijan economy, and then carefully test the theoretical hypotheses associated with this phenomenon. By dividing the economy into the three sectors, namely the oil, non-oil tradable, and non-tradable sectors, the author concludes that during the period 2000-2007 there has not been "absolute deindustrialization", but rather "relative deindustrialization" of the non-oil tradable sector, and that the non-tradable sector has substantially expanded (Corden \& Neary, 1982). The paper also shows that government expenditures have created a "spending 
effect", which is more crucial than the "resource movement effect". Furthermore, it was found that rapid increases in wages and non-tradable prices led to a real exchange rate (RER) appreciation in Azerbaijan. Finally, the study reveals that FDIs in the oil sector are harmful to non-oil exports and, therefore, deepen the natural resource dependence of the economy. The author also suggests, as a policy implication of the study, that the development of the non-oil tradable sector should be the major focus of policymakers in order to obtain a diversified economy and, consequently, long-term sustainable and balanced economic growth (Ibid).

Although the Azerbaijan economy has not been investigated systematically in terms of the Dutch disease phenomenon, some years ago (Rosenberg \& Saavalainen, 1998; Singh \& Laurila, 1999; Kronenberg, 2004; Kutan \& Wyzan, 2005; Égert, 2009) found empirical evidence similar to that obtained by (Hasanov, 2013), even though, in a Dutch disease in the Azerbaijan economy, their studies focused on a wider set of transition countries. For the period between 1995 and 1998, Rosenberg and Saavalainen (1998) show that because of the nature of resource prices, the Azerbaijan economy could be vulnerable to short-term recessions, as its RER has appreciated more than in other countries of the former Soviet Union, such as in Kazakhstan, Turkmenistan, and Uzbekistan, which is a result of nominal exchange rate appreciation and monetary conditions. On the contrary, Singh and Laurila (1999) conclude that the DUTCH DISEASE syndrome, seen through an appreciation in RER, is not a problem at the time, but may become one in the medium or long term. Initially, a Dutch disease reported that government revenues were highly leveraged on oil exports and that the financial intermediation process did not operate efficiently.

In the 1970s, the same economic condition occurred in Great Britain, when the price of oil quadrupled and it became economically profitable to drill the North Sea oil off the coast of Scotland (Acheampong \& Baah-Kumi, 2011). During the 1970s, Britain became a net exporter of oil, but it had previously been a net importer. Pound Sterling soared in value, but the country fell into recession when British workers demanded higher wages, and exports became uncompetitive. In this process, an increase in revenue from natural resource discovery will deindustrialise or de-agriculturalize a nation's economy by raising the exchange rate, which makes the manufacturing or agricultural sectors less competitive and public services entangled with business interests (Ibid). Ghana should learn from the above-mentioned paradigms in order not to fall into structural traps that would make her oil discovery a curse.

\subsection{Agricultural Sector Performance before and after the 0il}

Agriculture is considered the cornerstone of Ghana's economy and is central to the pursuit of sustainable development goals. As an agrarian economy, agriculture is said to be an engine of growth and poverty reduction in countries where it is the main occupation of the poor (World Bank, 2018). It is therefore not surprising that the Maputo declaration directed African countries to devote at 
least $10 \%$ of their national budget to agriculture. Ghana has seen consistent positive growth in per capita food production since the 1990s, and efforts are continuing in this direction.

Notwithstanding the progress in this sector, the economy remains vulnerable to external shocks due to its narrow resource and export base (ISSER, 2010: p. 105). According to a study by Dartey-Baah et al. (2012), the agricultural sector undoubtedly remains the largest sector of the Ghanaian economy, contributing 34.5 percent to GDP in 2009, an increase of $0.6 \%$ in the previous year. They attributed the agricultural sector performance in 2009 to two sub-sectors: crops/livestock and cocoa (6.2\% each) (Ibid). Cocoa, timber, and non-traditional agricultural exports provide major foreign exchange earnings for agriculture. Foreign exchange earnings from agriculture increased to US\$2197 million in 2009 from a 2007 figure of US\$1549 million, with cocoa (84.9\%), timber (8.2\%), and non-traditional agricultural exports (6.9\%) as the main contributors (Ibid).

It is notable that the investment and further development of the agricultural sector, particularly in cocoa production, is essential to avoid Dutch disease. A characteristic of countries that have experienced Dutch disease has come about when there has been a shift in focus. The phenomenon of Dutch disease shows a shift of focus and concentration from the agricultural and manufacturing sectors to the resource export and construction sectors, resulting in economic stagnation. From Figure 1, as adapted from Ackah (2016), it is obvious that the agricultural sector's performance declined significantly between 2009 and 2010 and continued to reduce until date (ACEP, 2018).

The statistics, as stipulated in Figure 1 and Figure 2 have consequences on Ghana's food sufficiency and have contributed to the huge import bill. It also has consequences for many rural poor who depend solely on the agricultural sector as a source of their livelihood since the sector's contribution to GDP has also

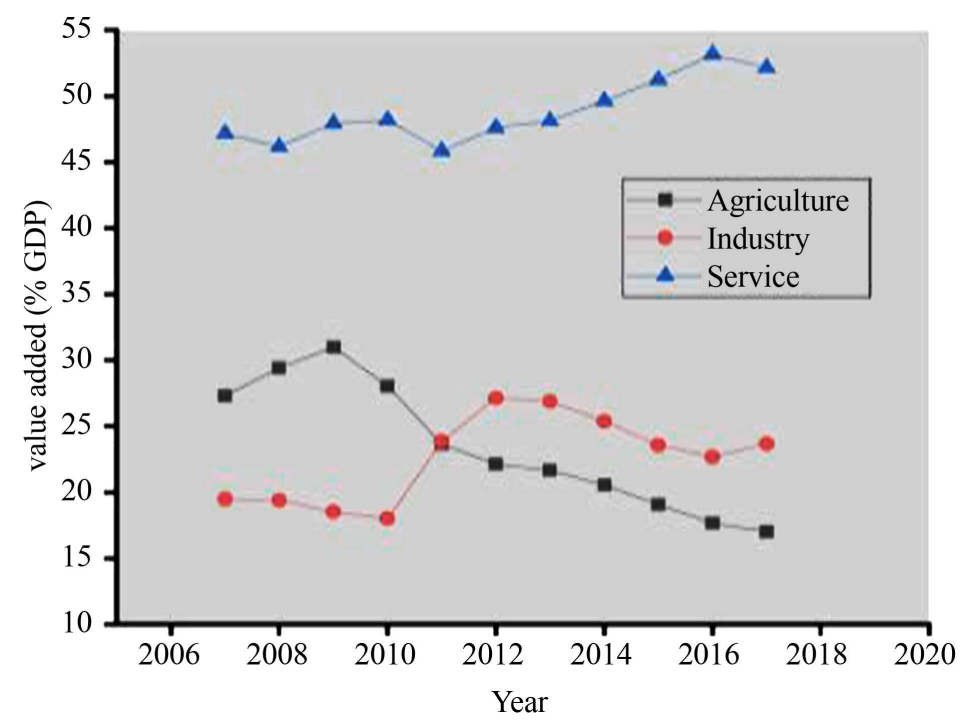

Figure 1. Value added (\% GDP) of the three sectors (Service, industry and agriculture). Source: World development indicators (WDI). 


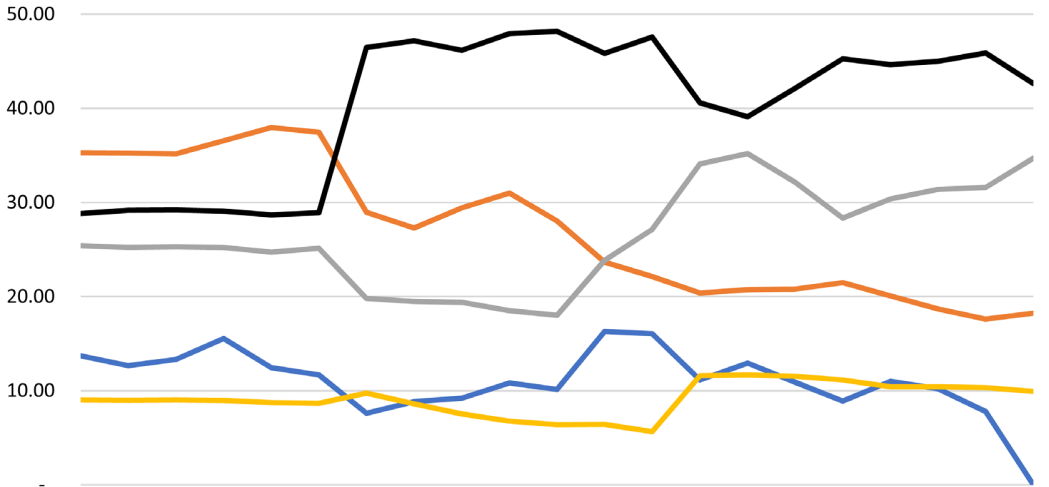

200020012002200320042005200620072008200920102011201220132014201520162017201820192020

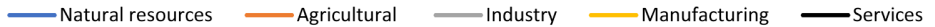

Figure 2. Trend in agricultural and other four main sectors contribution to GDP in Ghana. Source: Authors Calculation from Global Economy.com.

declined. As can be seen from Figure 1, the sector's contribution to GDP in 2010 was $29.8 \%$ and declined to $18.24 \%$ in 2020 . Figure 2 discusses the contribution of agriculture and other four main sectors including natural resources, where oil and gas feature prominently. From Figure 2, agriculture contributed $35.27 \%$ of Ghana's GDP in 2000 , decreased to $22.13 \%$ in 2012 , and $18.24 \%$ in 2020 . It is worth noting that just around the time when oil and gas were exploited on a commercial scale, the agricultural sector's performance reduced drastically with a corresponding increase in the oil industry and has remained, suggesting the symptoms of the Dutch disease.

\section{Discussion}

The extraction of oil in commercial quantities in the country gave hope to the citizens as revenues raked in through exports and the country became an oil exporter in the region besides Nigeria. As among the emerging markets and developing economies (EMDEs), the substantial decline in commodity prices since 2013 has slowed down capital accumulation and hence affected GDP growth in the next 10 years (World Bank, 2018). In 2017, the Government of Ghana started to extend free compulsory education to cover senior high schools by using petroleum revenues, making its sustainability going forward pessimistic (Fusheini et al., 2017). For such programs to be successful, the government must ensure a lot of resources and attention to the detriment of other sectors, such as agriculture, a backbone of the economy. The Daily Graphic report that according to the Finance Minister an amount of Ghana Cedis 7.62 billion has been spent for the past five years on funding the free senior high school (Graphic Online, 2021). These amounts were from two sources: the Government of Ghana (GOG) and Annual Budget Funding Amount (ABFA), which is a recipe for political consid- 
eration at the detriment of other sectors in the economy, fearing the Dutch disease syndrome. There has been a need for the government to diversify its sources of finance as dependence on oil revenue in the medium to long term would not make the free senior high school programme sustainable and thereby not spillover to the other sectors. Stringent macroeconomic decisions are often met with political considerations for fear of electoral backlash on the part of the ruling government. Therefore, the fragility of the democratic dispensation also contributed to the unstable economic outcome exacerbated by the COVID-19 outbreak.

\section{Conclusion and Policy Implication}

The main objective of this study was to ascertain whether the discovery of oil in Ghana has a negative effect on the agricultural sector, the most employable sector of the economy. To achieve this, we drew on the concept of the natural resource curse theory, the Dutch disease, to critically review the impact of Ghana's oil discovery on the performance of the agricultural sector through a desk review. Drawing on the experiences of other countries on Dutch disease, we argue that the dwindling performance of the agricultural sector after the oil discovery and dependence of oil revenue to finance the government flagship of Free Senior High School (SHS) programme are reflections of Dutch disease. We recommend that the government take proactive measures to ensure balance as well as engineer growth in the agricultural sector which absorbs most of the labour force (44.7\%). Measures such as youth in agricultural programmes, planting for food and jobs, subsidies, and recognition to successful farmers should be encouraged to ensure that the productive base of the sector is working. Modernising agriculture by introducing affordable technologies and increasing the number of extension assistance to farmers are added advantage in improving the capacity of farmers, leading to an increase in productivity. Diversifying government sources of funding the Free SHS would be an assurance to the public of sustainable funding amidst COVID-19 recovery of the economy to normalcy as well as easing global commodity supply restrictions.

\section{Authors' Contribution Statement}

George Asumadu conceived and drafted the opening, methodology, and conclusion. Daniel Ofori conducted his first review. John Agyei and Ali Yahuza Bawa conducted a second review.

\section{Conflicts of Interest}

The authors declare no conflicts of interest.

\section{References}

Abudu, H., \& Sai, R. (2020). Examining Prospects and Challenges of Ghana's Petroleum Industry: A Systematic Review. Energy Reports, 6, 841-858. 
https://doi.org/10.1016/j.egyr.2020.04.009

Acheampong, I. K., \& Baah-Kumi, B. (2011). The Dutch Disease in the Context of Ghana's Oil and Gas Find: The Plausible Economic Effects on the Ghanaian Economy. Indian Development Review, 9, 239-254.

Ackah, I. (2016). Sacrificing Cereals for Crude: Has Oil Discovery Slowed Agriculture Growth in Ghana?SSRN No. 2745904. https://doi.org/10.2139/ssrn.2745904

African Center for Energy Policy (ACEP) (2018). Is Agriculture Receiving Its Share of Ghana's Oil Money? Making a Case for Investment of Oil Revenues in Agricultural Development. https://acep.africa/file/2019/11/VFMAGRIC.pdf

Andrade, J. S., \& Duarte, A. P. (2017). Dutch Disease in Central and Eastern European Countries. In G. C. Pascariu, \& M. A. P. D. S. Duarte (Eds.), Core-Periphery Patterns across the European Union (pp. 113-141). Emerald Publishing Limited. https://doi.org/10.1108/978-1-78714-495-820171004

Aryeetey, E., \& Baah-Boateng, W. (2016). Understanding Ghana's Growth Success Story and Job Creation Challenges. WIDER Working Paper 2015/140, UNU-WIDER (World Institute for Development Economics Research). https://doi.org/10.35188/UNU-WIDER/2015/029-4 https://www.researchgate.net/publication/290445137_Understanding_Ghana\%27s_gro wth_success_story_and_job_creation_challenges

Barder, O. (2006). What Is Dutch Disease and Is It a Problem? Centre for Global Development.

Corden, M., \& Neary, P. (1982). Booming Sector and De-Industrialization in a Small Open Economy. Economic Journal, 92, 825-848. https://doi.org/10.2307/2232670

Corden, W. M. (1984). Booming Sector and Dutch Disease Economics: Survey and Consolidation. Oxford Economic Papers, 36, 359-380.

https://doi.org/10.1093/oxfordjournals.oep.a041643

Czech, K., \& Imbeah, N. (2019). Crude Oil Export of Ghana and Its Impact on the Economy. Annals of the Polish Association of Agricultural and Agribusiness Economists, 21, 53-63. https://doi.org/10.5604/01.3001.0013.5957

Dartey-Baah, K., Amponsah-Tawiah, K., \& Aratuo, D. (2012). Emerging "Dutch Disease" in Emerging Oil Economy: Ghana's Perspective. Society and Business Review, 7, 185-199. https://doi.org/10.1108/17465681211237637

Diao, X., Hazell, P. B. R., Kolavalli, S. L., \& Resnick, D. (2019). Ghana's Economic and Agricultural Transformation: Past Performance and Prospects. Oxford University Press. https://doi.org/10.1093/oso/9780198845348.001.0001

Égert, B. (2009). Dutch Disease in Former Soviet Union: Witch-Hunting? Discussion Papers No. 4, Bank of Finland Institute for Economies in Transition (BOFIT). https://doi.org/10.2139/ssrn.1383522

Elwerfelli, A., \& Benhin, J. (2018). Oil a Blessing or Curse: A Comparative Assessment of Nigeria, Norway and the United Arab Emirates. Theoretical Economics Letters, 8, 1136-1160. https://doi.org/10.4236/tel.2018.85076

Essegbey, G. O., \& MacCarthy, D. D. (2020). Situational Analysis Study for the Agriculture Sector in Ghana. CCAFS Report, CGIAR Research Program on Climate Change, Agriculture and Food Security (CCAFS). https://hdl.handle.net/10568/111562

Fusheini, A., Adam, A., Kuyole, E., Ibrahim-Tanko, R., \& Bekoe, S. (2017, March 22). Funding Ghana's "Free” Senior High School with Oil Revenue: Sober Reflection Required, Briefing. Natural Resource Governance Institute.

https://www.resourcegovernance.org 
Global Economy (2021). Ghana: GDP Share of Agriculture. https://www.theglobaleconomy.com/Ghana/Share_of_agriculture/

Graham, E., Ackah, I., Andrews, N., \& Gyampo, R. E. V. (2019). Escaping the "Oil Curse": Is Ghana on the Right Path? The African Review, 46, 235-263.

Graphic Online (2021). GhC7.62 Bn for Free SHS in 5 Years-Finance Minister. https://www.graphic.com.gh/news/general-news/gh-7-62bn-for-free-shs-in-5-years-fin ance-minister.html

Hasanov, F. (2013). Dutch Disease and the Azerbaijan Economy. Communist and PostCommunist Studies, 46, 463-480. https://doi.org/10.1016/j.postcomstud.2013.09.001

Henstridge, M., \& Roe, A. (2018). Macroeconomic Management of Natural Resources. In T. Addison, \& A. Roe (Eds.), Extractive Industries: The Management of Resources as a Driver of Sustainable Development (pp.161-178). Oxford University Press. https://doi.org/10.1093/oso/9780198817369.003.0008 https://oxford.universitypressscholarship.com/view/10.1093/oso/9780198817369.001.0 001/oso-9780198817369-chapter-8

Humphreys, M., Sachs, J. D., Stiglitz, J. E., Humphreys, M., \& Soros, G. (2007). Escaping Resource Curse. Columbia University Press.

Ibe, R. C., \& Ihejirika, U. A. (2018). Investigating the Dutch Disease (DD) in Nigeria Using Johansen Multivariate Cointegration Technique. International Journal of Innovative Finance and Economics Research, 6, 24-32.

ICAI (Institute of Chartered Accountants of India) (2020, February 12). Literature Review: The Changing Nature of UK Aid in Ghana. https://icai.independent.gov.uk/html-version/ghana-3/

ILO (International Labour Organization) (2020). Sector Skills Strategy: Agriculture Sector. https://www.ilo.org/wcmsp5/groups/public/ed_emp/ifp_skills/documents/publication/ wcms_754214.pdf

ISSER (Institute of Statistical, Social and Economic Research) (2010). State of the Ghanaian Economy in 2009. University of Ghana.

Itrade.gov.il (2021, May10). Agriculture Sector in Ghana Review. https://itrade.gov.il/ghana/files/2020/05/Agriculture-Sector-Review.pdf

Kapela, J. (2009). Ghana's New Oil: Cause for Jubilation or Prelude to the Resource Curse. MA Thesis Submitted to Duke University.

Kopiński, D., Polus, A., \& Tycholiz, W. (2013). Resource Curse or Resource Diseases. Oil in Ghana. African Affairs, 112, 583-601. https://doi.org/10.1093/afraf/adt056

Kronenberg, T. (2004). The Curse of Natural Resources in the Transition Economies. The Economics of Transition, 12, 399-426. https://doi.org/10.1111/j.0967-0750.2004.00187.x

Kumah-Abiwu, F., Brenya, E., \& Agbodzakey, J. (2015). Oil Wealth, Resource Curse, and Development: Any Lessons for Ghana? Journal of Economics and Sustainable Development, 6, 62-73.

Kutan, A., \& Wyzan, M. (2005). Explaining the Real Exchange Rate in Kazakhstan, 1996-2003: Is Kazakhstan Vulnerable to the Dutch Disease? Economic Systems, 29, 242-255. https://doi.org/10.1016/j.ecosys.2005.03.009

Kuzu, D., \& Nantogmah, D. (2010). The Oil Economy and Resource Curse Syndrome: Can Ghana Make a Difference? Friedrich-Ebert-Stiftung, Ghana Office.

Kwawukume, S. (2012). Ghana's Oil and Gas Discoveries: Towards Full Maximum Bene- 
fits (Revised ed.). Solomon Kwawukume.

Lashitew, A., \& Werker, E. (2020, July 16). Are Natural Resources a Curse or Blessing or a Double-Edged Sword?

https://www.brookings.edu/blog/future-development/2020/07/16/are-natural-resource s-a-curse-a-blessing-or-a-double-edged-sword/

Okpanachi, E., \& Andrews, N. (2012). Preventing the Oil "Resource Curse" in Ghana: Lessons from Nigeria. World Futures, 68, 430-450. https://doi.org/10.1080/02604027.2012.693854

Opoku, A., \& Emmanuel, B. (2021). Asymmetrical Effect of Oil and Gas Resource Rent on Economic Growth: Empirical Evidence from Ghana. Cogent Economics \& Finance, 9, Article ID: 1971355. https://doi.org/10.1080/23322039.2021.1971355

Oyesami, T. A. (2011). Investigating Dutch Disease: The Case of Nigeria. Master's Thesis, Eastern Mediterranean University.

Rosenberg, C., \& Saavalainen, T. (1998). How to Deal with Azerbaijan's Oil Boom? Policy Strategies in a Resource-Rich Transition Economy (Vol. 1998). Working Paper No. 98/6, International Monetary Fund. https://doi.org/10.5089/9781451929164.001

Rosnow, R. L., \& Rosenthal, R. (2002). Beginning Behavioral Research: A Conceptual Primer (4th ed.). Prentice-Hall, Inc.

Singh, R., \& Laurila, J. (1999). Azerbaijan: Recent Economic Developments and Policy Issues in Sustainability of Growth. Discussion Papers No. 5, Bank of Finland Institute for Economies in Transition (BOFIT). https://doi.org/10.2139/ssrn.1016675

Steffensen, L. S., Miettinen, M. S., Ekiz, D., Hansen, P. F., Kjær, M. C., Wolfhagen, J. M. et al. (2011). Oil Findings in Ghana.

https://core.ac.uk/download/pdf/12519975.pdf

Weinthal, E., \& Luong, P. (2006). Combining the Resource Curve: An Alternative Solution for Managing Mineral Wealth. Perspectives on Politics, 4, 35-53.

https://doi.org/10.1017/S1537592706060051

World Bank (2017a). Ghana Agriculture Sector Policy Note: Transforming Agriculture for Economic Growth, Job Creation, and Food Security. World Bank. https://openknowledge.worldbank.org/handle/10986/28394

World Bank (2017b). Mining in Africa: Are Local Communities Better Off? Africa Development Forum.

https://documents1.worldbank.org/curated/en/517391487795570281/pdf/112971-PUBPUBLIC.pdf

World Bank (2018). 3rd Ghana Economic Update: Agriculture as an Engine of Growth and Job Creation. World Bank Group.

https://www.wathi.org/wathinote-election-ghana-situation-economique/ghana-econo $\underline{\text { mic-update-agriculture-as-an-engine-of-growth-and-jobs-creation-world-bank-group/ }}$ 